\title{
AN EMPIRICAL ANALYSIS OF TOURIST SATISFACTION: A CASE-STUDY OF ZLIN-ZOO IN THE CZECH REPUBLIC
}

\author{
Mohsin JAVED* \\ Tomas Bata University in Zlin, Faculty of Management and Economics, Department of Business Administration, \\ nám. T. G. Masaryka 5555, 76001 Zlín, Czech Republic, e-mail: javed@utb.cz, mohsin1fcc@yahoo.com
}

\section{Zuzana TUČKOVÁ}

Tomas Bata University in Zlin, Faculty of Management and Economics, Department of Business Administration, nám. T. G. Masaryka 5555, 76001 Zlín, Czech Republic, e-mail: tuckova@utb.cz

\section{Abdul Bashiru JIBRIL}

Tomas Bata University in Zlin, Faculty of Management and Economics, Department of Management and Marketing, nám. T. G. Masaryka 5555, 76001 Zlín, Czech Republic, e-mail: jibril@utb.cz, mallambash13@gmail.com

\begin{abstract}
Citation: Javed, M., Tučková, Z., \& Jibril, A.B. (2020). AN EMPIRICAL ANALYSIS OF TOURIST SATISFACTION: A CASE-STUDY OF ZLIN-ZOO IN THE CZECH REPUBLIC. GeoJournal of Tourism and Geosites, 30(2spl), 852-860. https://doi.org/10.30892/gtg.302spl10-514
\end{abstract}

\begin{abstract}
This paper aims to assess the mediating role of tourist satisfaction based on certain antecedents and consequences for the fa mous zoo of the Moravian region in the Czech Republic. Relatively, the overlooked segment of the hospitality sector, particularly, the recreation segment is addressed by taking the case of the aforementioned zoo to analyze the antecedents and consequences of tourist satisfaction from visitors' viewpoints. Hence, the assessment of the mediating role of tourist satisfaction by taking the case of Zoo in the recreation segment is the novel aspect, due to its thorough investigation about the role of significant antecedents and consequences. Based on the primary data and application of the PLS-SEM, results indicated direct and indirect effects, the construct 'emotion' significantly affects tourist satisfaction as a direct effect. Tourist satisfaction also predicts the recommendation/WoM and corporate image significantly while only 'emotion' is signi ficant with respect to indirect effects. The study concludes that 'emotion' is an important antecedent for consideration, whilst recommendation/WoM, and corporate image are significant constructs of consequences related to tourist satisfaction. The study implications and limitations are considered whilst future research directions have been suggested in the end part of the paper.
\end{abstract}

Key words: Tourism, Tourist satisfaction, Recreation segment, Hospitality sector, Antecedents, Consequences, PLS-SEM, Zlin-Zoo, Czech Republic

\section{INTRODUCTION}

Travel and Tourism have emerged as a backbone of the service industry and are putting impacts on individuals' lives, society and economy in significant ways. With the passage of time, the growing number of tourists is evidence of such importance, as international tourist arrivals reached up to 1.4 million and international tourism receipts hit the recorded level of US\$ 1451 billion, in the year 2018 (World Tourism Organization, 2019). Tourism also accelerates economic growth and provides an avenue for unique opportunities in less developed countries (Crotti and Misrahi, 2017). From the previous three decades, the sustainability and competitiveness of the tourism industry are much debated issue. However, according to Eraqi (2006), the mere focus on prices and promotion for competitiveness is not enough, therefore, a novel approach with quality-oriented policies should be adopted. In this vein, the needs of the tourists should be catered and satisfaction should be enhanced due to their primary role in the tourism sector, and many researchers have raised this issue and bracketed enhanced tourist satisfaction with the success of tourism industry (Neal and Gursoy, 2008; Wu, 2007; Stevens et al., 1995).

Truong and Foster (2006) described that tourist satisfaction is the conformity between tourists' expectations and destinations' characteristics. According to this point of view, tourist satisfaction can be figured out by subjective factors (emotions and needs of tourists) and objective factors (features of the product and service). While literature indicates that there is no consensus and homogeneity regarding the concept of tourist satisfaction (Sanchez-Rebull et al., 2018). In light of this, the higher level of tourist satisfaction plays its role in the successfulness of a tourist destination and the same has been argued repeatedly that the satisfaction of tourists leads the tourists to revisit and make recommendations to friends and family (Chen and Chen, 2010; Lee et al., 2011). The revisit and make recommendations to others refer to the tourist loyalty and this loyalty according to Yuksel et al., (2010) can be effective, cognitive or conative in nature. In this study, tourist satisfaction denotes the positive emotions, feelings, and expectations expressed by tourists with respect to tourist visitation (Gallarza and Saura, 2006; Chi and Qu, 2008). Furthermore, the emotional enjoyment, the perception and image of destination as well as quality of provided services also contributes to tourist satisfaction (De Rojas and Camarero, 2008; Bigne et al., 2001; Chen and Tsai, 2007; Chen and Chen, 2010). Consequently, it can be regarded that tourist satisfaction is the combination of the features of a tourist destination and the perceptions of tourists (Hui et al., 2007). Despite the extensive literature on tourism and tourist satisfaction, the consensus about the antecedents of tourist satisfaction and the resulting consequences is lacking. This study will peep into the matter and put effort to fill this lacuna by doing an analysis of important antecedents and consequences of tourist satisfaction.

However, the available research on the antecedents of tourist satisfaction and consequences has been carried out extensively on hotels, travel $\&$ tourism, and food \& beverages whilst the recreation segment is somehow overlooked and even in some cases non-existent. Specifically, the investigation about the recreational zoos in terms of tourist satisfaction is very rare and this gap creates a need to do thorough analysis by contributing towards theory and practice. In view of this, the present study considers the case of Zlin-Zoo in the Moravian region of the Czech Republic due to its popularity and higher inflow of diverse tourists. From a theoretical perspective, this study will discover the consistencies of research construct related to the theme of this research under study. Whilst the managerial contribution will be beneficial to policymakers and 
management of Zoos to take inspiration from the proposed model as well as the found results that could help to boost the sector from the medium to long term sustainability. The rest of the paper has been organized as follows. The second section deals with the theoretical background of the precursors (drivers) as well as the resultant consequences of tourist satisfaction. The third section represents the development of a conceptual framework and research propositions. The fourth section gives the methodological part exploited in the present study. The fifth section provides the study implications to theory and practice. Finally, the sixth section recapitulates the study with the conclusion, limitations, and suggestions for future research directions.

\section{PRECURSORS AND CONSEQUENCES OF TOURIST SATISFACTION}

\section{Precursors:}

Emotions

Emotions in the literature are positive or negative thoughts or feelings that individuals or person exhibit. One of the most important and widely discussed drivers in the literature is emotions or positive emotions which have a direct relationship with the tourist satisfaction (Sanchez-Rebull et al., 2018). Abubakar and Mavondo (2014) used the driver, emotions, to analyze and isolate the factors which contribute to satisfaction and recommendation. Brunner-Sperdin et al., (2012) measured tourist satisfaction related to the emotions. Similarly; Chang (2008), Faullant et al. (2008), Gountas and Gountas (2007), Magnini et al. (2011), Mason and Paggiaro (2012), Moon et al. (2016), Richard and Zhang (2012), and William and Soutar (2009) also used emotions for analysis as the main driver of tourist satisfaction. In view of the strong impact of emotions on tourist satisfaction, we hypothesize that:

H1: Positive emotions/feelings at a tourist destination directly predict tourist satisfaction.

\section{Service Quality}

Service quality arises when comparing expected performance and perceived performance or actual performance of service delivery as a difference. It is regarded as one of the important drivers of tourist satisfaction (Sanchez-Rebull et al., 2018). Usually, service quality is measured by a multi-dimensional scale in which different factors exist. In the tourism and hospitality sector, service quality is basically based on tangible and intangible dimensions (Faullant et al., 2008; Choi and Chu, 2001; Gupta et al., 2007; Radojevic et al., 2015). Service quality exhibits a positive relationship with tourist satisfaction, that's why Chen et al., (2011) recommended the improvement of the service quality for enhancing tourist satisfaction. This prima-facie relation leads us to hypothesize that:

H2: Perceived service quality at a tourist destination directly predicts tourist satisfaction.

\section{Safety}

Safety and feelings of being safe and secure represent another driver of tourist satisfaction. Some authors also pointed out the same fact in their work, like Buckley et al., (2014) highlighted safety as a driver to analyze the particularities of Chinese tourist satisfaction. Further, Lee et al., (2010) also focused on the importance of safety to assess different satisfaction levels in Korea and Yuksel (2001) used the driver, safety as well among others. Another study by Imbeah et al., (2020) also highlighted the tourists' perceptions of safety and provided evidence about the increasing level of safety expectations among tourists. In view of this, we propose that:

H3: Adequate safety measures at the destination predicts tourist satisfaction

\section{Consequences:}

\section{Customer loyalty}

Customer loyalty in tourism is the most prevalent and analyzed in the tourist satisfaction perspective which is normally based on several dimensions (Sanchez-Rebull et al., 2018). Among these studied dimensions in the earlier research work, include customer revisit, customer recommendation, and positive word of mouth among visitors, etc. (Bigne et al., 2008; Campo-Martinez and Garau-Vadell, 2010; Lu et al., 2015).

\section{Customer revisit}

Customer revisit may refer to the repetition or repurchase intention of a particular product/service during recurrent visits. In light of this, tourist satisfaction at some tourist attraction or destination entices the customer to revisit. Customer revisit is an important consequence of the higher level of tourist satisfaction. Chen et al. (2011) found that customer revisits enhance destinations competitiveness. Depending upon the perceived value and satisfaction, revisits intentions are more in food tourists (Kim et al., 2011). Some more authors also highlighted the same consequence of tourist satisfaction to revisit or repurchase the product or service in the tourism sector (Su et al., 2016; Tanford et al., 2012; Tiru et al., 2010; Wan and Cheng, 2011; Yuksel, 2001). However, the previous visit to a tourist attraction also entices to revisit and make recommendations to friends and family, depending upon their feelings and opinions. Alegre and Cladera (2009) used the previous visit as a driver to distinguish drivers of tourist intentions. Castañeda et al. (2007) analyzed the previous visit to see the effect on customer satisfaction. On the parallel line, Chitty et al. (2007), Garcia-Crespo et al. (2011), Guiry and Scott (2013), Tsiotsou (2006), used the previous visit as a driver of tourist satisfaction. A recent study by Carvache-Franco et al. (2019) also pointed out the motivational and intentional factors playing the role for re-visitation and recommending to others in the geographical region of Costa Rica.

\section{Recommendation and positive Word-of-Mouth (WoM)}

A customer recommendation is a situation where a customer seeks to express positive expression about a product or service to a potential customer or buyer. This recommendation arises from the previous customer experience. Whist word-of-mouth signifies information given by some acquaintance or some other trusted source about the usefulness of a product or service (Nevada Small Business, 2019). Recommendations and positive word-of-mouth can be created by providing some free samples and consultations as well as delivering the promised and claimed quality. Previous studies also highlight the same as an important consequence of tourist satisfaction (Chen et al., 2011; Hultman et al., 2015; Lu et al., 2015; Tanford et al., 2012). Furthermore, WoM in the literature denotes the spread of verbal and non-verbal conversation. The conversation spreads from one person to another and so on so forth. Tourist destinations are equally vulnerable towards WoM when services and expectations from these destinations are met by potential or experienced visitors. We, therefore, hypothesize that:

H4: Tourist satisfaction positively and directly predicts customer loyalty (recommendation/WoM).

\section{Corporate goodwill}

The corporate goodwill is an intangible asset for tourism businesses which improves with the higher level of tourist satisfaction. Previous studies indicate the same along with the importance of corporate goodwill and image to the business. Mohamed (2007) carried a study about 
customer satisfaction and corporate image to analyze the influence of customer satisfaction on corporate goodwill and image and came out with the conclusion of a significant relationship. Very little research has been conducted on this relationship, and further is needed to explore this overlooked aspect in the zoo sector. To this end, we propose that:

H5: Tourist satisfaction positively and directly predicts corporate image.

With regard to the above analogy from the literature, we hypothesize the following indirect statements to capture the indirect impact of the underlying research constructs, and these propositions are stated below:

H6: Positive emotions/feelings have a significant indirect effect on recommendation/WoM and corporate image through tourist satisfaction.

H7: Perceived service quality has a significant indirect effect on recommendation/WoM and corporate image through tourist satisfaction.

H8: Adequate safety measures have a significant indirect effect on recommendation/WoM and corporate image through tourist satisfaction.

Having reviewed, the relevant literature of the abovementioned theme, the present study, therefore, proposes a research model (see figure 1) carved from previous related articles so as to discover the drivers (precursors) and consequences of tourist satisfaction depending upon visitors' experiences from the visitation of a particular destination. Also, adding to this model is the summary of research constructs and their respective literature sourced (Table 1).

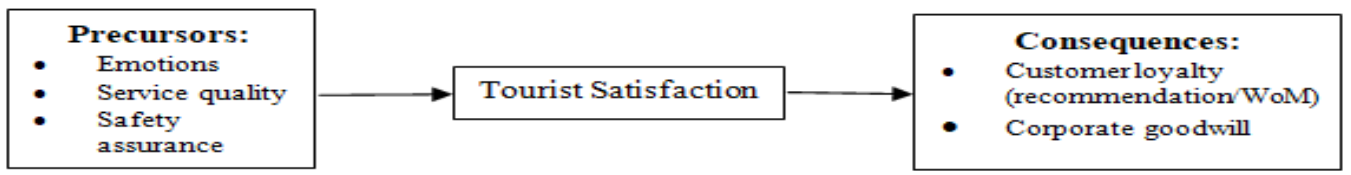

Figure 1. A proposed research framework from the literature

Table 1. Summary of research construct and literature sourced

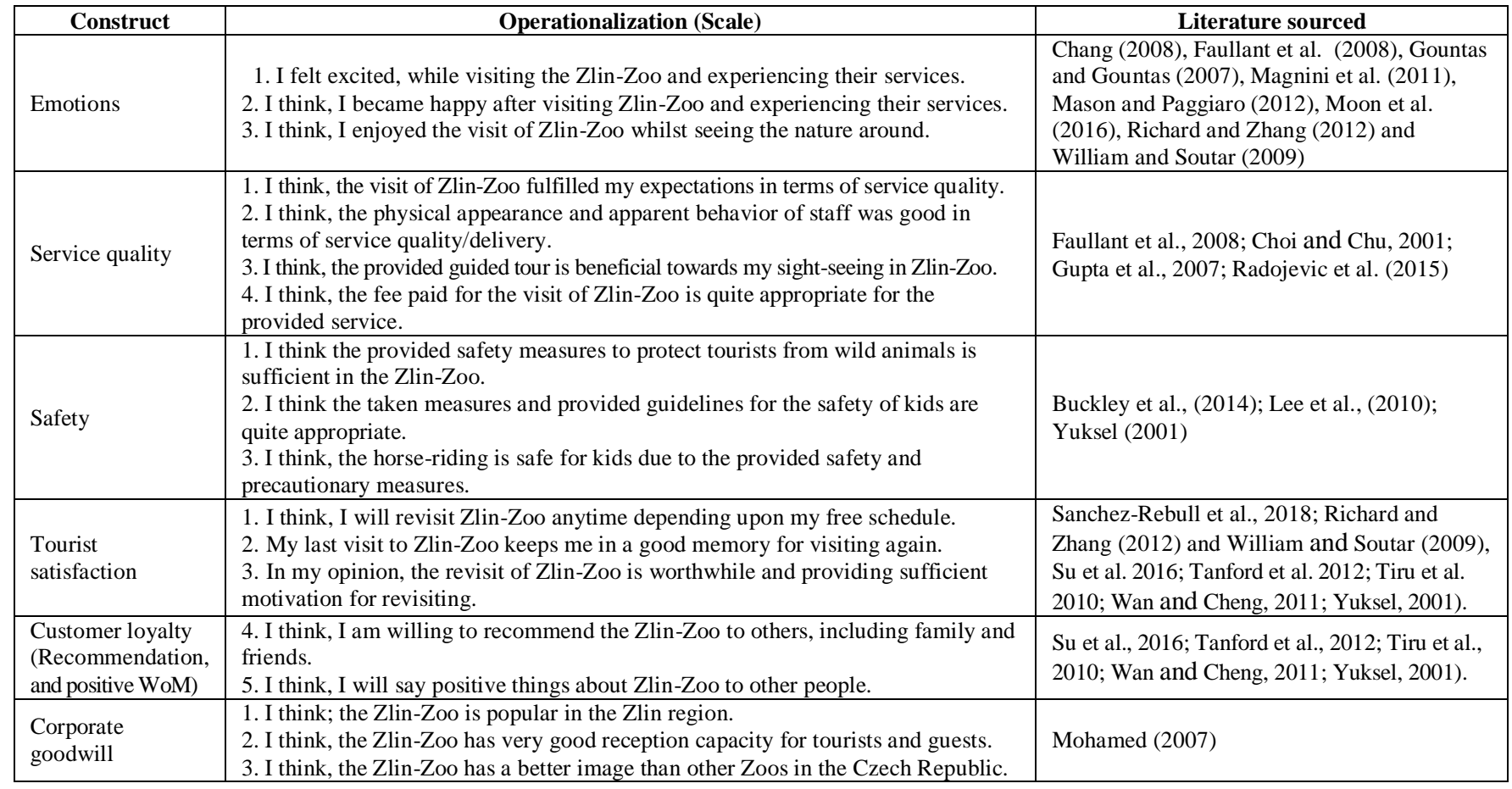

\section{RESEARCH METHODOLOGY}

\section{Study Area and its brief description}

The study areas is Zlin-Zoo which is a famous recreational and zoological garden situated by the Lešná castle, is almost 10 Kilometers away from downtown of Zlin. There are several interesting factors which make it worthwhile to visit. More importantly, ZlinZoo is the second largest zoo in the Czech Republic in terms of the number of visitors. The historical factor of the zoo also grabs attention of the visitors as the zoo was established in the year 1804. However, it was nationalized after the second world war and opened for the general public in the year 1948 (Municipal Information and Tourist Center, 2020).

The total area of the zoo is 74 hectares. Every year, more than 600,000 visitors visit the zoo and in the year 2018, the number of visitors were 648,375. The zoo is having about 1200 different animals from 226 species. The conservation program of zoo for rare species of animals in terms of reproduction and care is also worth-mentioning (Zlin-Zoo website, 2020). In addition, a botanical garden in the area is having 13000 kinds of plants. The newly built exhibition hall was opened in the year 2007, presents very rare species of almost 250 plants from tropical Yucatán. Again, as the Lešná castle is situated within the area of the Zlin-Zoo, it increases its importance as an attraction from visitation point of view. This Lešná castle is a historical mansion, displays rare collection of paintings, trophies and porcelain from the late nineteenth century (Municipal Information and Tourist Center, 2020). NB: Lešná (in Czech) translate to mean a 'forest' in English langauge.

\section{Data}

This research study exploited the quantitative research approach to analyze and assess tourist satisfaction in the case of Zlin-Zoo, which is a popular zoo in the Moravia region of the Czech Republic. For this purpose, a self-administered questionnaire has been developed and a survey has been carried out to gather data from the students and staff of Tomas Bata University in Zlin, Czech Republic. The structured self- 
administered questionnaire and online survey have been exploited to collect data and 170 questionnaires were distributed to students and staff of the university. Out of the 170 distributed questionnaires, 138 were valid and useable to proceed towards the analysis of data, representing 81 percent. By extension, these students composed of both local and international students who have visited the aforementioned zoo as at the time the data was collected. The aforementioned respondents have been selected through a non-probability sampling method, precisely the snowball sampling method. In this type of non-random sampling method, the respondents also refer and include their acquaintances to participate in the study. This method was suitable and convenient for the research due to accessibility, willingness to participate, proximity, participants' accessibility to the researcher, and cost-effectiveness, as these criteria among others, as suggested by Etikan et al., (2016). To execute the snowball sampling technique, initially, the questionnaire was sent to students and staff of the Tomas Bata University who subsequently forwarded to others to participate in this research.

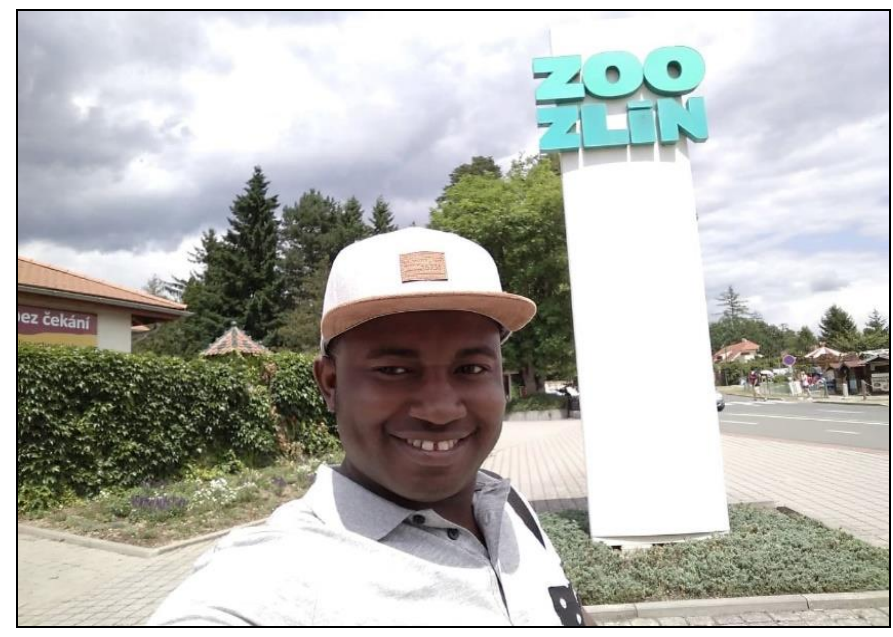

Figure 2. An international tourist visiting Zlin-Zoo

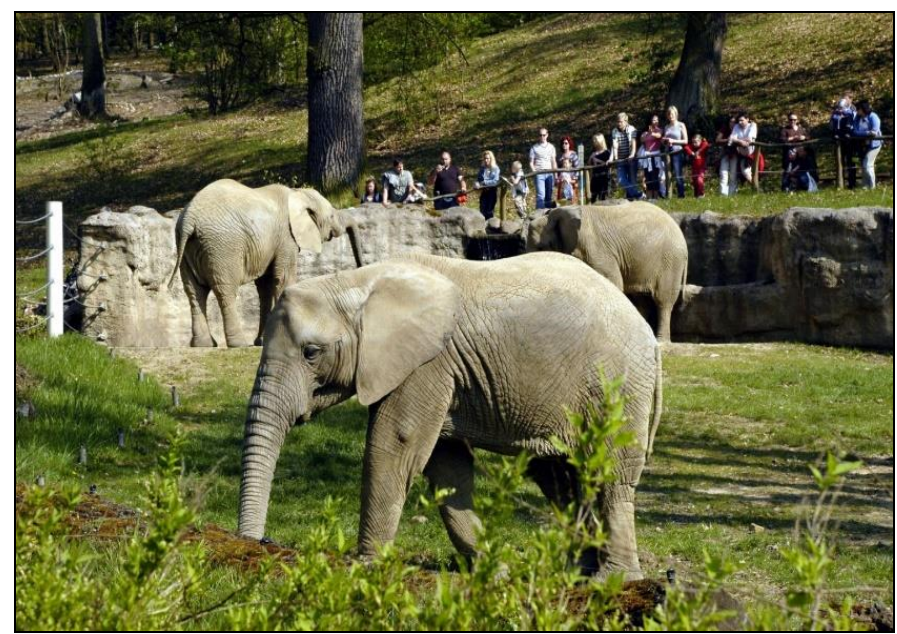

Figure 4. Tourists viewing animals

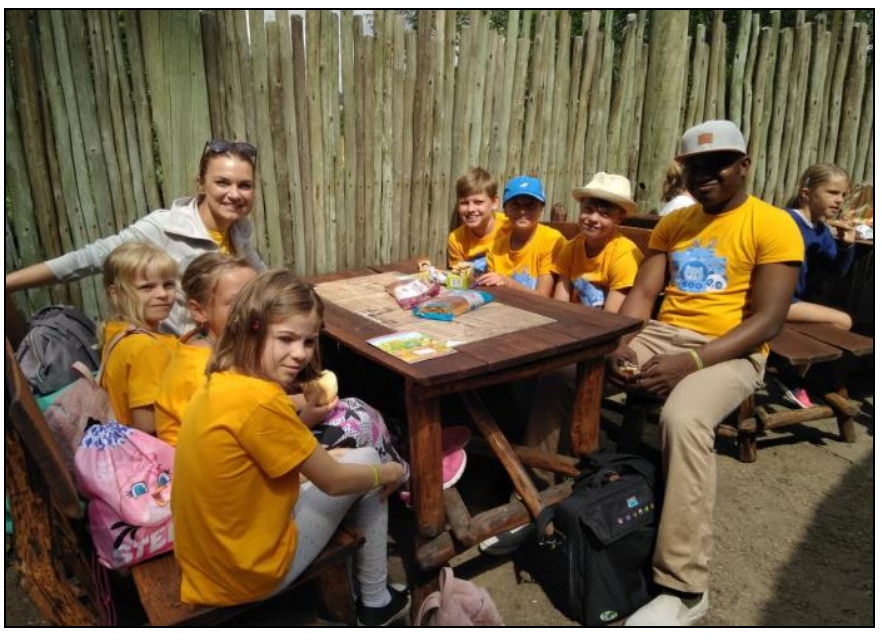

Figure 3. Tourists at Zlin-Zoo

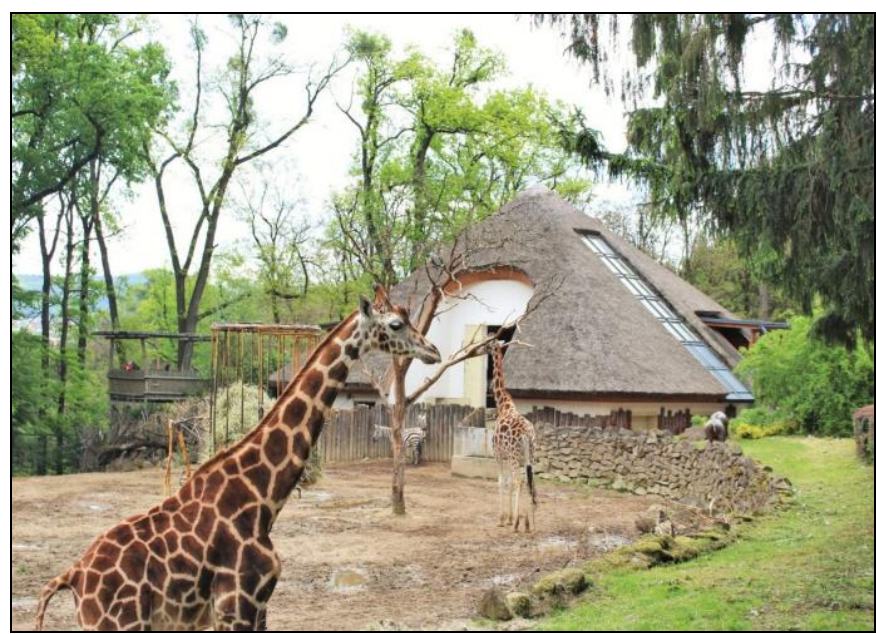

Figure 5. Precious specie Zebras at Zlin-Zoo

Table 2: Demographic profile of the respondents

\begin{tabular}{|l|l|c|c|}
\hline Variable & Details & Frequency & Percentage \\
\hline \multirow{4}{*}{ Gender } & Male & 53 & 38.4 \\
\cline { 2 - 4 } & Female & 85 & 61.6 \\
\hline \multirow{5}{*}{ Age (years) } & $15-25$ & 96 & 69.6 \\
\cline { 2 - 4 } & $26-35$ & 37 & 26.8 \\
\cline { 2 - 4 } & $36-45$ & 3 & 2.2 \\
\cline { 2 - 4 } & $46 \&$ above & 2 & 1.4 \\
\hline Educational Level & Bachelor diploma & 80 & 58.0 \\
\cline { 2 - 4 } & Master diploma & 28 & 20.3 \\
\cline { 2 - 4 } & PhD & 9 & 6.5 \\
\cline { 2 - 4 } & Others & 21 & 15.2 \\
\hline \multirow{4}{*}{ Occupational } & Student & 104 & 75.4 \\
\cline { 2 - 4 } & Private employed & 18 & 13.0 \\
\cline { 2 - 4 } & Government employed & 9 & 6.5 \\
\cline { 2 - 4 } & Others & 7 & 5.1 \\
\hline Category of & Locals/Domestic tourists & 89 & 64.5 \\
\cline { 2 - 4 } Respondents & Foreign tourist & 49 & 85.5 \\
\hline Marital Status & Single & 118 & 13.8 \\
\cline { 2 - 4 } & Married & 19 & 0.7 \\
\cline { 2 - 4 } & Divorced & 1 & $\mathbf{1 0 0}$ \\
\hline Total (n) & & $\mathbf{1 3 8}$ & \\
\hline \multirow{2}{*}{} & & & 9.5 \\
\hline
\end{tabular}


Table 2 below shows a summary of the demographic characteristics of the respondents included in the analysis for this research study. The demographic profile includes characteristics like gender, age, educational level, occupational status, category of respondents, and marital status of respondents. We acknowledge and emphasize that this research is the extension of the earlier work/article presented in the 3rd International Conference of Tourism Research (Javed et al., 2020) at the Universidad Europea de Valencia (UEV), in Valencia, Spain.

\section{Measures}

Apart from the demographic characteristics, all the remaining scales and measures have been adopted from the previous studies, published in reputable journals. In this regard, the measures of the constructs, emotion, service quality, safety, tourist satisfaction, and customer loyalty have been taken from the literature (Table 1). Further, it is important to mention that the opinions and responses were recorded through a five-point Likert scale, anchored with strongly agree $=5$, agree $=4$, natural $=3$, disagree $=2$, and strongly disagree $=1$.

\section{Analytical methods used}

A partial least squares Structural Equation Modeling (PLS-SEM) has been selected to apply for the statistical analysis and response evaluation. All the main constructs have also been tested for reliability and validity. The Structural Equation Modeling (SEM) is appropriate in such situations where opinions and perceptions are involved, and this same has been used by well-known researchers and has been recommended to apply in such situations (see Hair Jr et al., 2014; Reinartz et al., 2009). In addition, the applied PLS-SEM is also considered preferable when the nature of data is unknown in terms of common factor or composite base, and focus on the maximization of explained variances among research constructs.

\section{EMPIRICAL RESULTS}

The empirical results of PLS-SEM have been obtained by using ADANCO Version 2.1. We used PLS-SEM because of its advantage over CB-SEM of not requiring the condition of normally distributed data. However, there is no contradiction between the results from these two methods (Goodhue et al., 2012); hence, we used the PLS-SEM.

\section{Test of model fit (validity and reliability)}

As eminent scholars, like Hair et al. (2017) asserted to analyze and test the model for constructs reliability and internal consistency, so executed by Dijkstra-Henseler's rho along with Cronbach's alpha coefficients, respectively. Table 3 shows the satisfactory level of constructs' reliability as all the values are above the suggested threshold of 0.5 (Bagozzi and Yi, 1988; Hair et al., 2019). The analysis also fulfilled the requirements of composite reliability (CR) measured by Dijkstra-Henseler's rho and Joreskog's rho with the threshold levels of 0.8 and 0.7 , respectively.

Table 3: Construct Reliability and Validity Source: Authors' processing from ADANCO 2.1 Version

\begin{tabular}{|l|c|c|c|c|}
\hline \multicolumn{1}{|c|}{ Constructs } & Dijkstra-Henseler's rho $(\rho \mathrm{A})$ & Jöreskog's rho $(\rho \mathrm{c})$ & Average variance extracted $(\mathrm{AVE})$ & Cronbach's alpha $(\alpha)$ \\
\hline Tourist Satisfaction & 0.8345 & 0.8915 & 0.7329 & 0.8190 \\
\hline Emotions & 0.8269 & 0.8950 & 0.7397 & 0.8241 \\
\hline Service Quality & 0.7343 & 0.7903 & 0.4914 & 0.5624 \\
\hline Safety & 0.7685 & 0.7859 & 0.8676 & 0.6159 \\
\hline Recommendations/WoM & 0.8527 & 0.9291 & 0.6443 & 0.8477 \\
\hline Corporate Image & 0.7245 & 0.8445 & 0.7236 \\
\hline
\end{tabular}

With respect to factor loadings of the latent construct, all the items have been loaded sufficiently above the threshold level. Bagozzi and $\mathrm{Yi},(1988)$, reiterated that a factor loading above the threshold level of 0.6 is considered an adequate level of correlation coefficient (Table 4). In addition, the discriminant validity has been assessed through Fornell-Lacker's (1981) criterion, which ensures that a construct measure is unique and it represents the phenomenon of interest that other measures do not capture (Hair et al., 2005; Henseler et al., 2015). The results show that as per Fornell-Lacker's criterion both basic and stringent assumptions are satisfied and discriminant validity has been established. It is worthwhile to note that the diagonal values (in bold) of the Fornell-Lucker's table (Table 5) signify the AVE's and each measured construct must have the value of AVE greater than 0.5. As well as, the value of each construct's coefficient should be higher at both column and row position to establish the discriminant validity (Bagozzi and Yi, 1988; Fornell-Lacker, 1981; Henseler et al., 2015).

Table 4. Factor Loadings Source: Authors' processing from ADANCO 2.1 Version

\begin{tabular}{|c|c|c|c|c|c|c|}
\hline Indicators & Tourist Satisfaction & Emotion & Service Quality & Safety & Recommendation/WoM & Corporate Image \\
\hline EMO1 & & 0.8587 & & & & \\
\hline EMO2 & & 0.8797 & & & & \\
\hline EMO3 & & 0.8414 & & & & \\
\hline ServQual1 & & & 0.8625 & & & \\
\hline ServQual2 & & & 0.7163 & & & \\
\hline ServQual3 & & & 0.5863 & & & \\
\hline ServQual4 & & & 0.6041 & & & \\
\hline TSat1 & 0.8154 & & & & & \\
\hline TSat2 & 0.8705 & & & & & \\
\hline TSat3 & 0.8809 & & & & & \\
\hline Saf1 & & & & 0.8992 & & \\
\hline Saf2 & & & & 0.7869 & & \\
\hline Saf3 & & & & 0.5093 & & \\
\hline Recom/WoM1 & & & & & 0.9379 & \\
\hline Recom/WoM2 & & & & & 0.9249 & \\
\hline Corp1 & & & & & & 0.8253 \\
\hline Corp2 & & & & & & 0.8040 \\
\hline Corp3 & & & & & & 0.7781 \\
\hline
\end{tabular}


An Empirical Analysis of Tourist Satisfaction: A Case-Study of Zlin-Zoo in the Czech Republic

Table 5. Test of Discriminant Validity - Fornell-Lacker criterion (Data source: Authors' processing from ADANCO 2.1 Version)

\begin{tabular}{|l|c|c|c|c|c|c|}
\hline Constructs & Tourist Satisfaction & Emotions & Service Quality & Safety & Recommendation/WoM & Corporate Image \\
\hline Tourist Satisfaction & $\mathbf{0 . 7 3 2 9}$ & & & & & \\
\hline Emotions & 0.5202 & $\mathbf{0 . 7 3 9 7}$ & & & & \\
\hline Service Quality & 0.2542 & 0.4311 & $\mathbf{0 . 4 9 1 4}$ & & & \\
\hline Safety & 0.1250 & 0.1823 & 0.1853 & $\mathbf{0 . 5 6 2 4}$ & & \\
\hline Recommendation/WoM & 0.4950 & 0.4254 & 0.2248 & 0.1640 & $\mathbf{0 . 8 6 7 6}$ & \\
\hline Corporate Image & 0.3205 & 0.2862 & 0.2468 & 0.1237 & 0.3306 & $\mathbf{0 . 6 4 4 3}$ \\
\hline
\end{tabular}

\section{Structural Model-Hypotheses Testing}

The goodness of model fit can proceed with path analysis of the structural model. This analysis is quite relevant to identify and establish the causal-effects or relationships of the constructs of the underlying research prepositions and hypotheses. As a matter of fact, the specific direct and indirect effects related to tourist satisfaction can be discussed as below:

Direct effect

The results provide insights about the behavior of tourists with respect to service satisfaction of the famous Zlin-Zoo in the Moravian region of the Czech Republic. In this regard, the construct emotion (an antecedent of tourist satisfaction) has a significant impact on tourist satisfaction, shown by the values $(\beta=0.6758, t$-value $=8.5120)$, so, H1 hypothesis is supported, as shown in Table 6 . However, some constructs like service quality and safety (antecedents of tourist satisfaction) are impacting tourist satisfaction positively but insignificantly, the corresponding values showing the same $(\beta=0.0435$, $t$-value $=0.4796 ; \beta=0.0395$, $t$-value $=0.5903)$, so, $\mathrm{H} 2$ and $\mathrm{H} 3$ hypotheses are not supported in this study. Whilst the remaining constructs; recommendation/WoM and corporate image (as consequences of tourist satisfaction) are significant among the tourists visiting Zlin-Zoo, as the regression coefficient and test-statistic values showing, respectively; $(\beta=0.7039, t$-value $=13.0201 ; \beta=0.5665$, $t$-value $=10.2614)$, showing that $\mathrm{H} 4$ and $\mathrm{H} 5$ hypotheses are supported. The relationships with significant impacts and supporting the respective hypothesis are 'bold' and represented "Supported" in the empirical remarks column (see Table 6). Furthermore, Table 6 also shows Cohen's $\mathrm{f}^{2}$ which measures the effect size and tells about the strength of the relationships falling in the direct effect category. According to Cohen's $(1988,1992,2013)$ guidelines that the value of Cohen's $\mathrm{f}^{2}$ could be categorized as small, medium, or large according to the value (Selya et al., 2012). According to this criteria, three direct relationships of our hypotheses fall in the large effect size category, due to the Cohen's $\mathrm{f}^{2}$ value greater than $0.35\left(\mathrm{f}^{2}=0.9802, \mathrm{f}^{2}=0.4716, \mathrm{f}^{2}=0.5175\right)$.

Table 6. Path analysis: Direct and Indirect Effects (Data source: Authors' processing from ADANCO 2.1 Version)

\begin{tabular}{|c|c|c|c|c|c|}
\hline Direct Effects + Indirect Effects & Original Coefficients $(\beta)$ & Mean value & t-value & Cohens's $f^{2}$ & Empirical Remarks \\
\hline Tourist Satisfaction -> Recommendation/WoM & 0.7039 & 0.7053 & 13.0201 & 0.9802 & Supported \\
\hline Tourist Satisfaction -> Corporate Image & 0.5665 & 0.5784 & $\mathbf{1 0 . 2 6 1 4}$ & 0.4716 & Supported \\
\hline Emotions -> Tourist Satisfaction & 0.6758 & 0.6705 & 8.5120 & 0.5175 & Supported \\
\hline Emotions -> Recommendation/WoM & 0.4757 & 0.4748 & 6.0093 & & Supported \\
\hline Emotion -> Corporate Image & 0.3829 & 0.3878 & 6.5269 & & Supported \\
\hline Service Quality -> Tourist Satisfaction & 0.0435 & 0.0628 & 0.4796 & 0.0019 & Not Supported \\
\hline Service Quality -> Recommendation/WoM & 0.0306 & 0.0438 & 0.4815 & & Not Supported \\
\hline Service Quality -> Corporate Image & 0.0247 & 0.0376 & 0.4586 & & Not Supported \\
\hline Safety -> Tourist Satisfaction & 0.0395 & 0.0345 & 0.5903 & 0.0038 & Not Supported \\
\hline Safety -> Recommendation/WoM & 0.0278 & 0.0243 & 0.5904 & & Not Supported \\
\hline Safety -> Corporate Image & 0.0224 & 0.0196 & 0.5791 & & Not Supported \\
\hline
\end{tabular}

\section{Indirect Effect}

The indirect effects are also an important part of the structural model, showing how variables are getting affected indirectly. Table 6 shows that the construct emotion has an indirect and significant impact on both constructs, i.e., recommendation/WoM and corporate image $(\beta=0.4757, t$-value $=6.00 ; \beta=0.3829, t$-value $=6.52$, respectively). Whilst the indirect effect of constructs; service quality and safety are insignificant, as t-values indicate that constructs showing relationships, like service quality to recommendation/WoM, service quality to corporate image, safety to recommendation and safety to the corporate image are all insignificant (Table 6).

Coefficient of determination $(r)$

The coefficient of determination has been assessed to analyze the predictive power of the studied constructs. The value of the coefficient of determination can be interpreted as the percentage of the variation in the dependent variable that has been explained by the independent variable (Miles, 2014). The coefficient of determination values shown in table 7 is explaining adequate variability (see also figure 6). However, some researchers like Colton and Bower (2002), are of the view that a high number of variables included in the model will lead to overfitting of the model, so researchers should be cautious, however, our case is different and goodness of fit is adequate. Therefore, $\mathrm{R}^{2}$ of tourist satisfaction (0.5235) shows $52 \%$ of the total variation in the construct has been explained by the independent constructs (emotion, service quality and safety). Table 7 depicts $\mathrm{R}^{2}$ of recommendation/WoM $(0.4955)$ which shows approximately $50 \%$ of the variability in the construct has been explained by tourist satisfaction (independent construct), whilst the $\mathrm{R}^{2}$ of the corporate image $(0.3210)$ shows $32 \%$ of the variation in the construct has been explained by tourist satisfaction (independent construct).

Table 7. Coefficient of Determination (Predictive Power of Constructs)

\begin{tabular}{|l|c|c|}
\hline Constructs & Coefficient of Determination $\left.\mathbf{( R}^{\mathbf{2}}\right)$ & Adjusted $\mathbf{R}^{\mathbf{2}}$ \\
\hline Tourist Satisfaction & 0.5235 & 0.5122 \\
\hline Recommendation/WoM & 0.4955 & 0.4915 \\
\hline Corporate Image & 0.3210 & 0.3157 \\
\hline
\end{tabular}

\section{DISCUSSION AND STUDY IMPLICATIONS}

The current research focused to explore the antecedents and consequences of tourist satisfaction of guests visiting the Zlin-Zoo of the Moravian region of the Czech Republic. The study came up with interesting results and insights. The construct; emotion as an important antecedent of tourist satisfaction has a significant impact on tourist satisfaction, this finding is quite in line with the work of other researchers (see Abubakar and Mavondo, 2014; Chang, 2008; Faullant et al., 2008). In this vein, Abubakar and Mavondo (2014) found the same by 
isolating the factors contributing to customer satisfaction in tourism. Chang (2008) pointed out the same role of emotions towards customer satisfaction. Again, the study conducted by Faullant et al., (2008) is somehow exhaustive as they recognized and acknowledged the role of emotions towards customer satisfaction in tourism and they explored the role of emotions to influence satisfaction by taking data of 67 cities in Alpine ski resorts. Moon et al., (2016) also highlighted the significant role of customer emotions and level of tourist satisfaction. Therefore; the assessment of emotion construct as an antecedent of tourist satisfaction is compatible with the results of previous studies (Abubakar and Mavondo, 2014; Chang, 2008; Faullant et al., 2008). The current study also found that some other constructs, like service quality and safety, are having an insignificant impact on tourist satisfaction in the zoo sub-sector, however, safety has a direct and indirect positive but weak relationship with tourist satisfaction, recommendation/WoM, as well as corporate image. In this regard, pre vious works are with mixed results. The study of Ali (2016) analyzed that the quality of the hotel website could impact considerably on the satisfaction of customers and purchase intentions, however, this finding does not contradict with this study because the current study is dealing with the service quality at Zlin-Zoo which is different than in hotels. Buckley et al., (2014) also found and suggested that safety measures and good safety equipment would increase the satisfaction of tourists for raft tours, whilst the relationship of safety and tourist satisfaction is different than safety measures in adventurous tourism. In addition, the assessed consequences of tourist satisfaction, recommendation/WoM, and corporate image have been significantly impacted by the tourist satisfaction. On the parallel lines, Chen et al. (2011), explored the role of customer satisfaction towards the recommendation, revisit increase, and competitiveness in 17 cities of Taiwan and found that a higher level of tourist satisfaction will lead to a recommendation. Mohamed (2007) investigated the influences of customer satisfaction on the corporate images by taking a sample of 3 cities in Egypt and reported a significant impact on corporate image. The aforementioned studies support well that tourist satisfaction puts a significant impact on recommendation/WoM and corporate image (Chen et al., 2011; Mohamed, 2007).

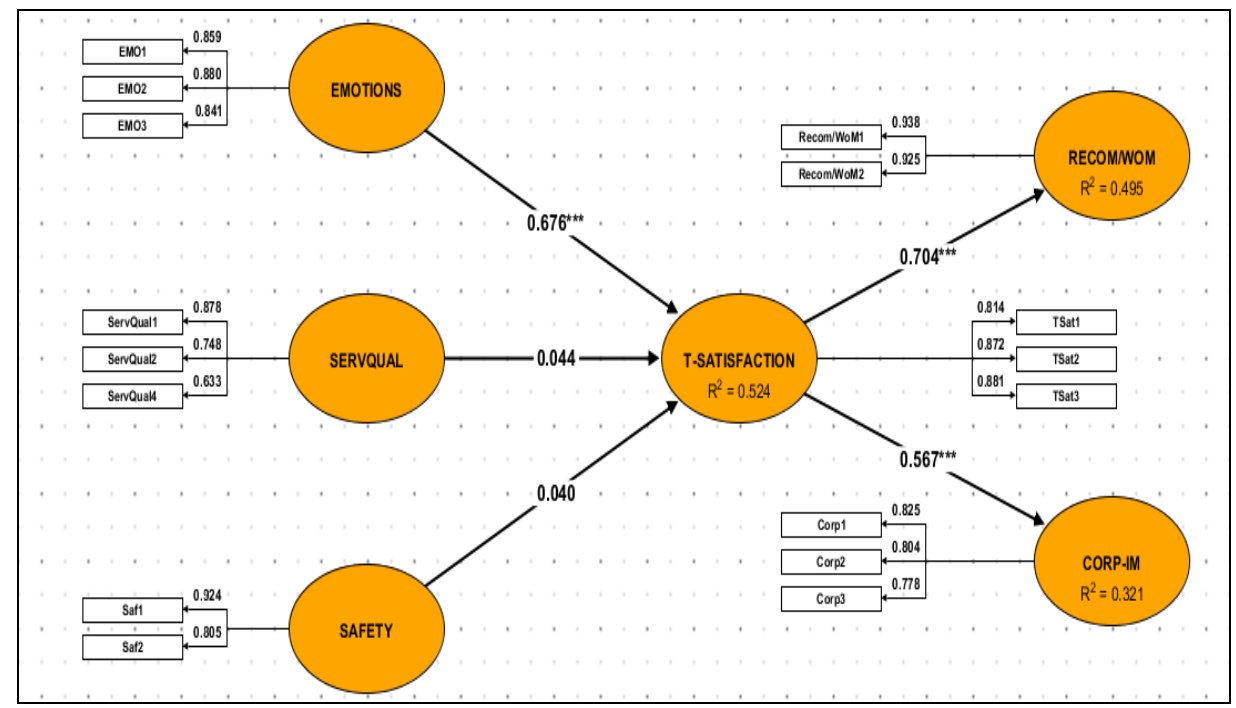

Figure 6. Estimated research model (Source: Authors' processing from ADANCO 2.1 Version)

This study also has important theoretical and practical relevance. In the theoretical vein, this study highlighted some important and prevalent precursors/drivers as well as consequences of tourist satisfaction. More importantly, the offered conceptual model is quiet helpful for better understanding the relationships and invites other interested researchers to peep in the matter and investigate the reliability and validity of the proposed model. Further, the reviewed and analyzed precursors and consequences draw the attention of the scholars interested in the tourist satisfaction regarding the relevant constructs and items found in the existing literature. The chosen and assessed precursors and consequences have important managerial implications for the selected case of Zlin-Zoo. It is important to note that the antecedent construct; emotion has a positive and significant effect on tourist satisfaction. This suggests that managers of Zlin-Zoo, as well as other domestic zoos, should do more to make visitors feel better at their first sight since their first-time experience gives them the impression to know whether to go for a revisit. In addition, tourist satisfaction also impacts on the other two constructs of consequences; recommendation/WoM and corporate image. Therefore, the managers of the Zoo should put every effort to enhance the level of tourist satisfaction in order to get more recommendations and improved corporate image so as to make the zoo business more competitive and sustainable with a higher level of long-term growth.

\section{CONCLUSION, LIMITATIONS AND FUTURE DIRECTIONS}

The main goal of this study was to assess the satisfaction of the tourists visiting the famous Zlin-Zoo of Moravian region in the Czech Republic. In this regard, some important constructs related to the antecedents and consequences have been identified from the literature. Using the quantitative method, a structured questionnaire has been used to carry out the survey for collecting data from the students and staff of Tomas Bata University in Zlin, the Czech Republic who had a regular visit to the said zoo. Partial Least Squares-Structural Equation Modeling (PLS-SEM) has been applied to analyze the collected data and results reveal interesting insights about the antecedents and consequences of tourist satisfaction. With respect to mediation analysis; emotion came as a construct putting indirect significant impact on recommendation/WoM and corporate image through tourist satisfaction and supported hypotheses H6, H7, and H8. However, service quality and safety are insignificant to tourist satisfaction so hypothesis 2 and hypothesis 3 are not supported in this study. The consequences of tourist satisfaction are also shedding light on important perspectives. The Hypotheses 4 and 5 related to consequences are also supported in this study i.e., tourist satisfaction positively and significantly impacts recommendations/WoM and corporate image, respectively.

Like every study, some limitations are worthwhile to highlight for readers to better understand the scope of the study and also for future research endeavors. Firstly, the results and findings should also be validated and verified for other zoos to cover a wider spectrum. Secondly, this research study used a relatively small sample size and the included respondents are only the students and staff of Tomas Bata University in Zlin, so, the results cannot be generalized. Therefore, future researchers should include more respondents of diverse nature (cross-section) with a probability sampling technique to generalize the findings. Thirdly, during the analysis of tourist satisfaction, only the viewpoint and perspective of the visitors have been included while the viewpoint of zoo administration/management has been overlooked; therefore, the 
authors acknowledge this limitation and suggest future researchers adopt a mixed-method approach for thorough investigation and consideration of the viewpoint of the managers and administrators of the zoo.

\section{Acknowledgment}

The authors are grateful for the financial assistance provided by the Internal Grant Agency of FaME, TBU No. IGA/FaME/2020/005, titled, "The sustainability practices in the eco and rural tourism" and project no. FSR-S/2020/FaME/001, to carry out this research.

\section{REFERENCES}

Abubakar, B., \& Mavondo, F. (2014). Tourism destinations: Antecedents to customer satisfaction and positive word-of-mouth. Journal of Hospitality Marketing \& Management, 23(8), 833-864.

Alegre, J., \& Cladera, M. (2009). Analysing the effect of satisfaction and previous visits on tourist intentions to return. European Journal of Marketing, 43(5-6), 670-685.

Ali, F. (2016). Hotel website quality, perceived flow, customer satisfaction and purchase intention. Journal of Hospitality and Tourism Technology, 7(2), 213-228.

Bagozzi, R.P., \& Yi, Y. (1988). On the evaluation of structural equation models. Journal of the Academy of Marketing Science, 16(1), 74-94.

Bigne, J. E., Mattila, A.S., \& Andreu, L. (2008). The impact of experiential consumption cognitions and emotions on behavioral intentions. Journal of Services Marketing, 22(4), 303-315.

Bigne, J.E., Sanchez, M.I., \& Sanchez, J. (2001). Tourism image, evaluation variables and after purchase behaviour: inter-relationship. Tourism Management, 22(6), 607-616.

Brunner-Sperdin, A., Peters, M., \& Strobl, A. (2012). It is all about the emotional state: Managing tourists' experiences. International Journal of Hospitality Management, 31(1), 23-30.

Buckley, R., McDonald, K., Duan, L., Sun, L., \& Chen, L.X. (2014). Chinese model for mass adventure tourism. Tourism Management, $44,5-13$.

Campo-Martínez, S., \& Garau-Vadell, J.B. (2010). The generation of tourism destination satisfaction. Tourism Economics, 16(3), 461-475.

Carvache-Franco, M., Víquez-Paniagua, A.G., Carvache-Franco, O., Perez-Orozco, A., \& Carvache-Franco, W. (2019). Motivations, Intentions to return and to recommend protected areas: a study in Costa Rica. GeoJournal of Tourism and Geosites, 27(4), 1173-1183.

Castañeda, J.A., Frías, D.M., \& Rodríguez, M.A. (2007). The influence of the Internet on destination satisfaction. Internet Research, 17(4), 402-420.

Chang, J. C. (2008). Tourists' satisfaction judgments: An investigation of emotion, equity, and attribution. Journal of Hospitality \& Tourism Research, 32 (1), 108-134.

Chen, C.F., \& Chen, F.S. (2010). Experience quality, perceived value, satisfaction and behavioral intentions for heritage tourists, Tourism Management, 31 (1), $29-35$.

Chen, C.M., Chen, S.H., \& Lee, H.T. (2011). The destination competitiveness of Kinmen's tourism industry: exploring the interrelationships between tourist perceptions, service performance, customer satisfaction and sustainable tourism. Journal of Sustainable Tourism, 19(2), 247-264.

Chen, R.S., \& Tsai, C.C. (2007). Gender differences in Taiwan university students' attitudes toward web-based learning. Cyberpsychology \& Behavior, $10(5), 645-654$.

Chi, C.G.Q., \& Qu, H. (2008). Examining the structural relationships of destination image, tourist satisfaction and destination loyalty: An integrated approach. Tourism Management, 29(4), 624-636.

Chitty, B., Ward, S., \& Chua, C. (2007). An application of the ECSI model as a predictor of satisfaction and loyalty for backpacker hostels. Marketing Intelligence \& Planning, 25(6), 563-580.

Choi, T.Y., \& Chu, R. (2001). Determinants of hotel guests' satisfaction and repeat patronage in the Hong Kong hotel industry. International Journal of Hospitality Management, 20(3), 277-297.

Cohen, J. (1992). Statistical power analysis. Current Directions in Psychological Science, 1(3), 98-101.

Cohen, J. (2013). Statistical power analysis for the behavioral sciences. Routledge.

Cohen, J.E. (1988). Statistical Power Analysis for the Behavioral Sciences. Hillsdale, NJ: Lawrence Erlbaum Associates, Inc.

Colton, J.A., \& Bower, K. M. (2002). Some misconceptions about R². International Society of Six Sigma Professionals, EXTRAOrdinary Sense, 3(2), $20-22$.

Crotti, R., \& Misrahi, T. (2017). The Travel \& Tourism Competitiveness Report 2017. Paving the way for a more sustainable and inclusive future. In World Economic Forum: Geneva, Switzerland.

De Rojas, C., \& Camarero, C. (2008). Visitors' experience, mood and satisfaction in a heritage context: Evidence from an interpretation center. Tourism Management, 29(3), 525-537.

Eraqi, M.I. (2006). Tourism services quality (TourServQual) in Egypt: The viewpoints of external and internal customers. Benchmarking: An International Journal, 13(4), 469-492.

Etikan, I., Musa, S.A., \& Alkassim, R.S. (2016). Comparison of convenience sampling and purposive sampling. American journal of theoretical and applied statistics, 5(1), 1-4

Faullant, R., Matzler, K., \& Füller, J. (2008). The impact of satisfaction and image on loyalty: the case of Alpine ski resorts. Managing Service Quality: An International Journal, 18(2), 163-178.

Fornell, C., \& Larcker, D.F. (1981). Evaluating structural equation models with unobservable variables and measurement error. Journal of Marketing Research, 18(1), 39-50.

Gallarza, M.G. \& Saura, I.G. (2006). Value dimensions, perceived value, satisfaction and loyalty: an investigation of university students' travel behavior. Tourism Management, 27(3), 437-452.

García-Crespo, Á., López-Cuadrado, J.L., Colomo-Palacios, R., González-Carrasco, I., \& Ruiz-Mezcua, B. (2011). Sem-Fit: A semantic based expert system to provide recommendations in the tourism domain. Expert Systems with Applications, 38(10), 13310-13319.

Goodhue, D.L., Lewis, W., \& Thompson, R. (2012). Does PLS have advantages for small sample size or non-normal data?. Mis Quarterly, 981-1001.

Gountas, J., \& Gountas, S. (2007). Personality orientations, emotional states, customer satisfaction, and intention to repurchase. Journal of Business Research, 60(1), 72-75.

Guiry, M., Scott, J.J., \& Vequist IV, D.G. (2013), Experienced and potential medical tourists' service quality expectations. International Journal of Health Care Quality Assurance, 26(5), 433-446.

Gupta, S., McLaughlin, E., \& Gomez, M. (2007). Guest satisfaction and restaurant performance. Cornell Hotel and Restaurant Administration Quarterly, 48(3), 284-298.

Hair Jr, J.F., Sarstedt, M., Hopkins, L., \& Kuppelwieser, V.G. (2014). Partial least squares structural equation modeling (PLS-SEM). European Business Review, 26(2), 106-121.

Hair, J.F., Risher, J.J., Sarstedt, M., \& Ringle, C.M. (2019). When to use and how to report the results of PLS-SEM. European Business Review, 31 (1), 2-24.

Hair, J., Babin, B., Money, A., \& Samouel, P. (2005). Fundamentos de métodos de pesquisa em administração. Bookman Companhia Ed.

Hair, J., Hollingsworth, C.L., Randolph, A.B., \& Chong, A.Y.L. (2017). An updated and expanded assessment of PLS-SEM in information systems research. Industrial Management \& Data Systems.

Henseler, J., Ringle, C.M., \& Sarstedt, M. (2015). A new criterion for assessing discriminant validity in variance-based structural equation modeling. Journal of the Academy of Marketing Science, 43(1), 115-135.

Hui, T.K., Wan, D., \& Ho, A. (2007). Tourists' satisfaction, recommendation and revisiting Singapore. Tourism Management, $28(4), 965-975$.

Hultman, M., Skarmeas, D., Oghazi, P., \& Beheshti, H.M. (2015). Achieving tourist loyalty through destination personality, satisfaction, and identification", Journal of Business Research, 68(1), 2227-2231.

Imbeah, N., Khademi-Vidra, A., \& Bujdoso, Z. (2020). Assessment of tourists' perceptions on safety at the Cape Coast tourist destination in Ghana. GeoJournal of Tourism and Geosites, 28 (1), 217-231.

Javed, M., Tučková, Z., \& Jibril, A.B. (2020). An Assessment of Tourist Satisfaction: A Review of Some Precursors and Consequences. In ICTR 2020 3rd International Conference on Tourism Research (p. 322). Academic Conferences and publishing limited. 
Kim, Y.H., Kim, M., \& Goh, B.K. (2011). An examination of food tourist's behavior: Using the modified theory of reasoned action. Tourism Management, 32(5), 1159-1165.

Lee, J.S., Lee, C.K., \& Choi, Y. (2011). Examining the role of emotional and functional values in festival evaluation. Journal of Travel Research, 50(6), 685-696.

Lee, K.W., Kim, H.B., Kim, H.S., \& Lee, D.S. (2010). The determinants of factors in FIT guests' perception of hotel location. Journal of Hospitality and Tourism Management, 17(1), 167-174.

Lu, C., Berchoux, C., Marek, M.W., \& Chen, B. (2015). Service quality and customer satisfaction: qualitative research implications for luxury hotels. International Journal of Culture, Tourism and Hospitality Research, 9, 168-182.

Magnini, V.P., Crotts, J.C., \& Zehrer, A. (2011). Understanding customer delight: An application of travel blog analysis. Journal of Travel Research, $50(5)$, $535-545$.

Mason, M.C., \& Paggiaro, A. (2012). Investigating the role of festival scape in culinary tourism: The case of food and wine events. Tourism Management, 33(6), 1329-1336.

Miles, J. (2014). R squared, adjusted R squared. Wiley StatsRef: Statistics Reference Online.

Mohamed, G.A.A. (2007). Service Quality of Travel Agents: The Viewpoint of Tourists in Egypt. Tourismoa, 2(1), 63-88.

Moon, H., Yoon, H.J., \& Han, H. (2016). Role of airport physical environments in the satisfaction generation process: Mediating the impact of traveller emotion. Asia Pacific Journal of Tourism Research, 21(2), 193-211.

Neal, J.D., \& Gursoy, D. (2008). A multifaceted analysis of tourism satisfaction. Journal of Travel Research, 47(1), 53-62.

Radojevic, T., Stanisic, N., \& Stanic, N. (2015). Ensuring positive feedback: Factors that influence customer satisfaction in the contemporary hospitality industry. Tourism Management, 51, 13-21.

Reinartz, W., Haenlein, M., \& Henseler, J. (2009). An empirical comparison of the efficacy of covariance-based and variance-based SEM. International Journal of research in Marketing, 26(4), 332-344.

Richard, J.E., \& Zhang, A. (2012). Corporate image, loyalty, and commitment in the consumer travel industry. Journal of Marketing Management, $28(5-6)$, 568-593.

Sanchez-Rebull, M.V., Rudchenko, V., \& Martín, J.C. (2018). The antecedents and consequences of customer satisfaction in tourism: a systematic literature review. Tourism and Hospitality Management, 24(1), 151-183.

Selya, A. S., Rose, J. S., Dierker, L. C., Hedeker, D., \& Mermelstein, R. J. (2012). A practical guide to calculating Cohen's f2, a measure of local effect size, from PROC MIXED. Frontiers in Psychology, 3, 111.

Stevens, P., Knutson, B. and Patton, M. (1995). DINESERV: A tool for measuring service quality in restaurants. The Cornell Hotel and Restaurant Administration Quarterly, 36(2), 5-60.

Su, L., Swanson, S.R., \& Chen, X. (2016). The effects of perceived service quality on repurchase intentions and subjective well-being of Chinese tourists: The mediating role of relationship quality. Tourism Management, 52, 82-95.

Tanford, S., Montgomery, R., \& Hertzman, J. (2012). Towards a model of wine event loyalty. Journal of Convention \& Event Tourism, 13(2), 77-99.

Tiru, M., Kuusik, A., Lamp, M.L., \& Ahas, R. (2010). LBS in marketing and tourism management: measuring destination loyalty with mobile positioning data. Journal of Location Based Services, 4(2), 120-140.

Truong, T.H. \& Foster, D. (2006). Using HOLSAT to evaluate tourist satisfaction at destinations: The case of Australian holidaymakers in Vietnam. Tourism Management, 27(5), 842-855.

Tsiotsou, R. (2006). Using visit frequency to segment ski resorts customers. Journal of Vacation Marketing, 12(1), 15-26.

Wan, P.Y.K., \& Cheng, E.I. (2011). Service quality of Macao's world heritage site. International Journal of Culture, Tourism and Hospitality Research, 5(1), 57-68.

Williams, P., \& Soutar, G.N. (2009). Value, satisfaction and behavioral intentions in an adventure tourism context. Annals of Tourism Research, 36 (3), 413-438.

Wu, C.H.J. (2007). The impact of customer-to-customer interaction and customer homogeneity on customer satisfaction in tourism service-the service encounter prospective. Tourism Management, 28(6), 1518-1528.

Yuksel, A. (2001). Managing customer satisfaction and retention: A case of tourist destinations, Turkey. Journal of Vacation Marketing, 7(2), 153-168.

Yuksel, A., Yuksel, F., \& Bilim, Y. (2010). Destination attachment: Effects on customer satisfaction and cognitive, affective and conative loyalty. Tourism Management, 31(2), 274-284.

*** IGI Global (2019). Available at: https://www.igi-global.com/dictionary/a-business-model-for-accessible-tourism/30292 [Online]. Retrieved on: 20 October, 2019.

*** MEDLIK, S. (2003). Turismo e hospitalidade no século XXI. Editora Manole Ltda.

*** Municipal Information and Tourist Center (2020). Available at: http://www.ic-zlin.com/24996-the-zoo-and-the-lesna-chateau [Online]. Retrieved on: 12 March, 2020.

*** Nevada Small Business (2019). Available at: https://nevadasmallbusiness.com/create-positive-word-of-mouth-the-best-advertising-for-business-is-free/ [Online]. Retrieved on: 19 November, 2019.

*** Zlin-Zoo (2020). Available at: https://www.zoozlin.eu/ [Online]. Retrieved on: 11 March, 2020.

*** World Tourism Organization (1995). Concepts, Definitions and Classifications for Tourism Statistics. Technical Manual No. 1. Madrid, UNWTO.

*** World Tourism Organization (2019). Available at: https://www2.unwto.org/press-release/2019-01-21/international-tourist-arrivals-reach-14-billion-twoyears-ahead-forecasts [Online]. Retrieved on: 11 October, 2019. 